\title{
Synthesis and Characterization of Nano-fibrillated Cellulose Derived from Green Agave americana L. Fiber
}

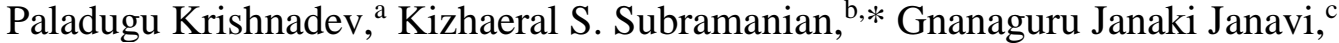 \\ Shanmugam Ganapathy, ${ }^{\mathrm{d}}$ and Arunachalam Lakshmanan ${ }^{\mathrm{a}}$
}

\begin{abstract}
Excessive exploitation of petroleum-based plastics and synthetic fibers is harming the environment. This study isolated nano-fibrillated cellulose (NFC) from plant fiber (Agave americana). The as-extracted Agave fibers were chemically treated (alkali, bleaching, and acid hydrolysis coupled with ultrasonication). Functional and structural analysis were performed using Fourier-transform infrared spectroscopy and X-ray diffraction. The surface morphological changes and thermal decomposition behavior were studied by scanning electron microscopy and by thermogravimetry and derivative thermogravimetry, respectively. Fourier-transform infrared peaks confirmed the absence of lignin and hemicellulose in the NFC samples. X-ray diffraction data revealed that the crystallinity index increased from $50.1 \%$ to $64.1 \%$ from the raw fiber to the NFC. Thermogravimetry and derivative thermogravimetry showed that the stability increased notably from the raw fiber to the NFC stage. The average particle size was $18.2 \mathrm{~nm} \pm 10.14 \mathrm{~nm}$ in the NFC sample, which was confirmed by transmission electron microscopy.
\end{abstract}

Keywords: Agave americana fiber; Acid hydrolysis; Ultrasonication; Nano-fibrillated cellulose; FT-IR; XRD; TGA-DTG; SEM; TEM

Contact information: a: Department of Nano Science \& Technology, Tamil Nadu Agricultural University, Coimbatore-641003, Tamil Nadu, India; b: Director of Research, Tamil Nadu Agricultural University, Coimbatore-641003, Tamil Nadu, India; c: Department of Vegetable Science, Horticultural College and Research Institute, Tamil Nadu Agricultural University, Periyakulam East, Theni-625604, Tamil Nadu, India; d: Department of Food \& Agricultural Process Engineering, Tamil Nadu Agricultural University, Coimbatore-641003, Tamil Nadu, India; *Corresponding author: drres@tnau.ac.in

\section{INTRODUCTION}

The time has come to address the environmental issues caused by the excessive usage and dumping of petroleum-based plastics. Various investigators in India and around the world are paying special attention to addressing these issues by developing eco-friendly renewable materials derived from natural plant fibers (Ramesh et al. 2017). These plant-derived fibers are widely available around the world and being studied due to their properties including biodegradability, biocompatibility, higher strength, higher aspect ratio, low density, low cost, good availability and reduced health hazard. The three types of naturally derived fibers that are commonly available are categorized by their origin: plant, animal, and mineral fibers (Bismarck et al. 2005). Plant-based fibers are otherwise known as cellulosic fibers because of their high cellulose content. Biocomposites are made by incorporating biologically derived materials into a biodegradable polymer matrix, along with other additives, to yield a characteristic composite material. The importance and usage of bio-composites have greatly increased in recent years, as they provide an alternative to petroleum-derived plastics (Rosli et al. 2013). Also, the 
material is sustainable and renewable.

Cellulose is a versatile polymer and is obtained from nature on a large scale. The most common sources include cotton, hemp, palm, pineapple, jute, flax, agave, sisal, and banana pseudostem, among others (Ramesh et al. 2017). The annual biomass contribution of cellulose is estimated to be $10^{12}$ tons (Nascimento et al. 2018). Cellulose comprises primary and secondary cell walls. Approximately, the primary cell walls constitute more than $15 \%$ to $30 \%$ of the total dry mass, while the secondary cell walls constitute more than $40 \%$ of the total dry mass (Nascimento et al. 2018). Cellulose is a semi-crystalline polysaccharide macromolecule, comprising a long, extended chain of d-anhydroglucose $\left(\mathrm{C}_{6} \mathrm{H}_{10} \mathrm{O}_{5}\right)$ units, which are well organized by $\beta$ - $(1-4)$-glycosidic bonds. The individual glucose monomers of cellulose, with $\mathrm{OH}$ groups. For each anhydroglucose unit there is one primary $\mathrm{OH}$ group, which is positioned at $\mathrm{C}_{6}$, while secondary $\mathrm{OH}$ groups are positioned at $\mathrm{C}_{2}$ and $\mathrm{C}_{3}$, forming strong intra-inter molecular hydrogen bonds and yielding good crystalline and amorphous packing of cellulose (Brinchi et al. 2013).

Nanofibrillated cellulose (NFC) comprises nanoscale cellulose fibrils with a long, flexible, entangled network; the diameters of the fibrils that comprise this material are typically in the range of $1 \mathrm{~nm}$ to $100 \mathrm{~nm}$. These nanoscale cellulose fibrils exhibit good tensile strength, uniform surface area, good ratio of diameter to fibril length, high axial Young's modulus, low specific density, good surface modifiability, and good biodegradability (Oksman and Sain 2006; Brinchi et al. 2013). From NFCs one can develop attractive thin films (Hubbe et al. 2017). Nanofibrillated cellulose has been successfully isolated from sugar palm (Arenga pinnata) fibers through high pressure homogenization process (Ilyas et al. 2019). Tanpichai et al. (2019) studied and isolated nanofibrillated cellulose from bamboo microfibers by the method of steam explosion. Marinho et al. (2020) successfully isolated and produced nanofibrillated cellulose from ramie fibers by alkaline organosolv and bleaching process; the resulting NFC and exhibited good physical, mechanical and barrier properties.

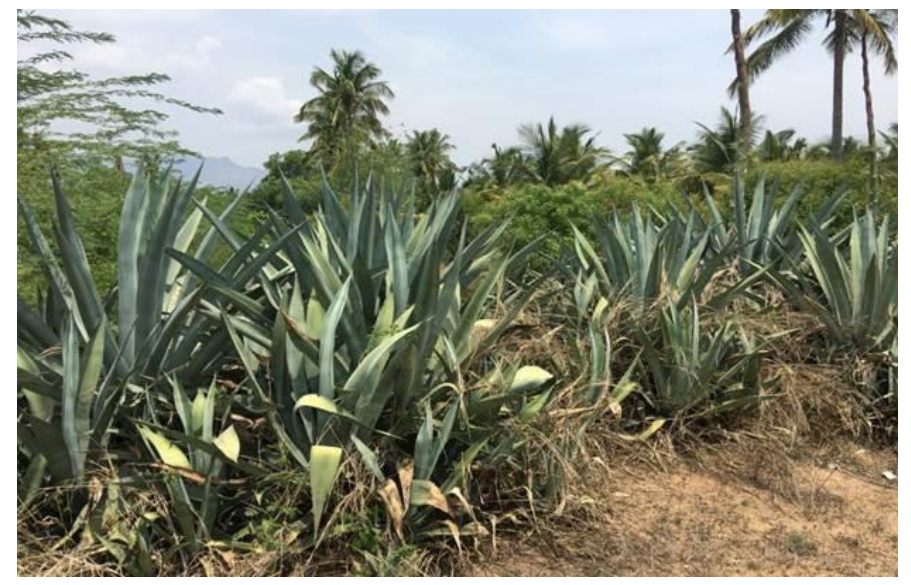

Fig. 1. Photograph of Agave americana L. plants

Agave americana L. is primarily known for its succulent plant; it is one of approximately 140 to 275 species of the Agave genus, belonging to the family Asparagaceae. The juice is usually extracted from the core of the plant and has many useful benefits, with good antimicrobial and antiseptic properties and a cellulose content of $60 \%$ to $80 \%$ (Msahli et al. 2005; Kolte et al. 2012). The matured and rosette leaves are harvested from the third year from the date of planting. The leaf length is approximately 
$150 \mathrm{~cm}$ to $250 \mathrm{~cm}$, and each plant yields approximately 40 to 50 plant leaves per year. The life span of the plant is 30 years. The dry mass of fiber varies from $2.5 \%$ to $4.5 \%$ (Kolte et al. 2012). The leaves are silvery-grey in appearance (Fig. 1).

In India, Agave species are grown in the dry zones of Tamil Nadu, Andhra Pradesh, Odisha, Maharashtra, Madhya Pradesh, Karnataka, Jharkhand, and West Bengal (Singh et al. 1999). They are grown along roadsides, railway lines, and river banks, and they are also good hedge plants. Farmers from different districts of Tamil Nadu obtain the fibers from Agave leaves, and they are made into different products, including ropes, handicrafts, garments, yarns, twines, carpets, and mats. In India, Agave fiber annual production is estimated to be approximately 12 tonnes, but the large-scale requirement of Agave fiber is approximately 50 tonnes. Annually, India purchases Agave from other countries including Tanzania and Kenya at a value of INR 25 millions. However, India exports twines and ropes to Nepal and Fiji that are made from Agave fiber (Sarkar and Sarcar 1996). The Global scenario of Agave fiber production was 39,925 thousand tons in 2017 of which Columbia shares about $48.52 \%$ of total production (FAOSTAT, 2017).

In this study, NFC was extracted and isolated from Agave americana L. plant fiber. The fiber was chemically pre-treated with alkali and bleaching, followed by acid hydrolysis with nitric acid and acetic acid in combination with ultrasonication. The fiber functionality and the structural, morphological, and thermal decomposition properties of the synthesized NFC were studied using Fourier-transform infrared spectroscopy (FTIR), X-ray diffraction (XRD), thermogravimetry (TG), derivative thermogravimetry (DTG), scanning electron microscopy (SEM), and transmission electron microscopy (TEM).

\section{EXPERIMENTAL}

\section{Materials}

The mature Agave leaves used in this study were harvested from the Thondamuthur village of Coimbatore city in Tamil Nadu, India. The chemical reagents used were sodium chlorite $\left(\mathrm{NaClO}_{2}\right.$, HiMedia, Mumbai, India), acetic acid glacial $(99 \%$, S. D. Fine-Chem Limited, Mumbai, India), and sodium hydroxide (NaOH, S. D. FineChem Limited, Mumbai, India). Nitric acid (69\% to $72 \%$ AR grade, S. D. Fine-Chem Limited, Mumbai, India) was already available in the laboratory. All used reagents were analytical grade.

\section{Methods}

Extraction of cellulose from Agave americana fibers

The sharp thorns present on the mature Agave leaf margins and the tip at the apex portion were removed using a sharp knife. The initial weight of the leaves to be extractable was recorded, and the final weight was recorded after fiber extraction using a simple, custom-made Raspador machine, which was available at the Tamil Nadu Agricultural University ECO-Green Unit (Coimbatore, Tamil Nadu, India). The asextracted fiber was transported to the lab and weighed. The fiber was allowed to dry completely for $24 \mathrm{~h}$ at $60{ }^{\circ} \mathrm{C}$ in an oven. The oven-dried fibers were used for the alkali treatment, bleaching, and acid hydrolysis to yield NFC. Prior to that, the fibers were cut into small pieces of $1 \mathrm{~cm}$ to $2 \mathrm{~cm}$ and ground using a mill to yield a fine powder. Then ground fibers were alkali treated with $2 \% \mathrm{w} / \mathrm{v}$ to $4 \% \mathrm{w} / \mathrm{v}$ of $\mathrm{NaOH}$ at $80{ }^{\circ} \mathrm{C}$ in a hot water bath for $2 \mathrm{~h}$ followed by bleaching treatment which was performed using $2 \% \mathrm{w} / \mathrm{v}$ of 
$\mathrm{NaClO}_{2}$ at $80{ }^{\circ} \mathrm{C}$ in a hot water bath for $4 \mathrm{~h}$ followed by acid hydrolysis using precisely $2.5 \mathrm{~g}$ of the fibers were treated with $20 \mathrm{~mL}$ of nitric acid $(70 \%)$ and acetic acid (80\%) at $100{ }^{\circ} \mathrm{C}$ in a hot water bath for $30 \mathrm{~min}$. Then, the fiber suspension was allowed to cool and was washed with distilled water until the fiber appeared to be white. Each fiber treatment was repeated twice, and the fibers were washed with distilled water after each treatment.

Fiber recovery yield, fiber yield percentage, moisture percentage, fiber length, fiber diameter, and chemical composition analysis

The percentage of fiber recovery can be determined from the amount of extracting biomass. Fiber recovery is given as a percentage (in this case, of Agave americana fiber).

The fiber recovery percentage and fiber yield were estimated and calculated using Eq. 1 (Syracuse University 2011):

$$
\text { Recovery }(\%)=\frac{\text { Weight of the fiber }(\mathrm{g})}{\text { Weight of fiber extractable leaves }(\mathrm{g})} \times 100
$$

The complex of lignocellulosic materials consisted of polysaccharides, microfibrillated cellulose, hemicelluloses, holocellulose, lignin, and other extracts. Using Eq. 2, the fiber yield percentage was calculated.

$$
\text { Fiber Yield }(\%)=\frac{\text { Weight of the dried fiber }(\mathrm{g})}{\text { Weight of fiber after decortified }(\mathrm{g})} \times 100
$$

The leaf fibers were chemically analyzed to determine the holocellulose (cellulose and hemicellulose) and lignin content. The sodium chlorite method of analysis was used to determine the holocellulose content. Approximately $2.5 \mathrm{~g}$ of the raw fibers was used for the analysis; the complete methodology is detailed elsewhere (Rowell 2012). The amount of lignin present in the fiber was analyzed according to the modified ASTM D1166-84 (2001) method. Each experiment was replicated in three sets, and the standard deviations were calculated.

\section{Moisture calculation}

After fiber extraction at the Tamil Nadu Agricultural University ECO-Green Unit, moisture calculation was performed by a set of three replications. The initial weight of Agave fiber was recorded using a precise weighing balance. Then, it was stored at less than $60{ }^{\circ} \mathrm{C}$ for $24 \mathrm{~h}$ in a hot-air oven and weighed to determine the dry weight of the sample. The moisture content of the fiber was calculated using Eq. 3 (Naik et al. 2013).

$$
\text { Moisture }(\%)=\frac{\text { Fresh weight }- \text { Dry weight }}{\text { Fresh weight }} \times 100
$$

\section{Fiber length and diameter measurements}

To determine the average fiber length and diameter after extraction, the fibers were straightened, and length measurements of random single fibers were made using a meter stick followed by diameter measurement using a digital caliper (resolution: $0.1 \mathrm{~mm}$ / 0.01 in.; accuracy: $\pm 0.2 \mathrm{~mm} / 0.01$ in.). Sets of 30 and 20 measurements were taken for length and diameter, respectively. The length and diameter were represented in $\mathrm{cm}$ and $\mathrm{mm}$. 
Isolation of NFC from Agave americana fibers

The methodological routes to obtain NFC from Agave fibers are depicted in Fig. 2.

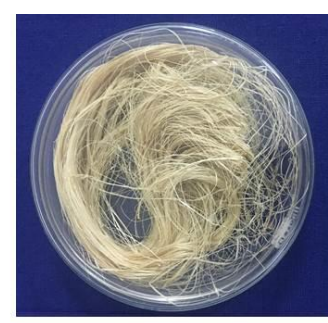

Extracted Fiber

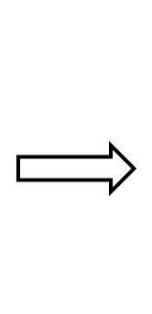

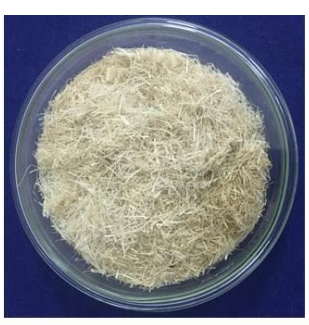

Chopped Fiber

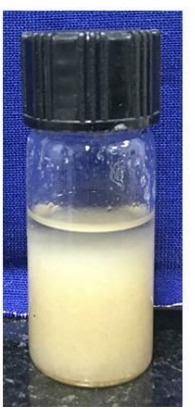

Bleached Treated
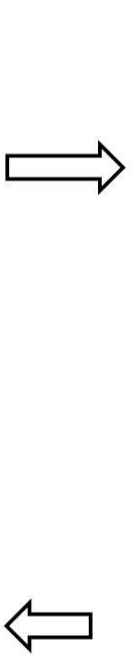

$2 \% \mathrm{NaClO}_{2}$ $80^{\circ} \mathrm{C}$

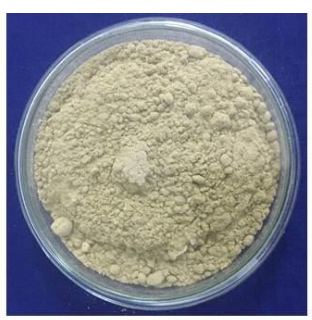

Milled Fiber

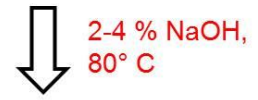

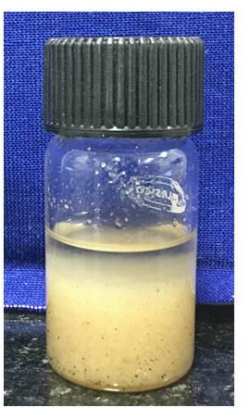

Alkali Treated

Followed by Ultrasonication

Fig. 2. Scheme for NFC Production from Agave americana fibers

The isolated cellulose was suspended in $10 \mathrm{~mL}$ of ethanol and ultrasonicated (Citizon, Digital Ultrasonic Cleaner, CD 48202.5 liters, Citizen Scales (India) Pvt Ltd) for $30 \mathrm{~min}$. For three replications, the NFC yield was calculated using Eq. 4 (Gopinathan et al. 2017).

$$
\text { Nanofibrillated cellulose yield }(\%)=\frac{\text { Weight of dried NFC cellulose (g) }}{\text { Weight of the fiber used for extraction (g) }} \times 100 \text { (4) }
$$

\section{Characterization and Analysis}

\section{FTIR analysis}

Fourier-transform infrared spectra of the milled raw Agave fibers, microcrystalline cellulose (MCC), and NFC samples were recorded using a Jasco 6800 (JASCO Corporation, Tokyo, Japan) in the range 400 to $4000 \mathrm{~cm}^{-1}$ with a scanning resolution of $4 \mathrm{~cm}^{-1}$. Before analysis, all of the samples were milled into a fine powder and dried for $6 \mathrm{~h}$ at $60{ }^{\circ} \mathrm{C}$ in a hot-air oven. All the samples were analyzed by the attenuated total reflection (ATR) method (ATR Pro One, JASCO Corporation, Tokyo, Japan).

XRD analysis

X-ray diffraction analysis was performed using a Rigaku Ultima IV diffractometer (Tokyo, Japan) at $40 \mathrm{kV}$ and $30 \mathrm{~mA}$ with $\mathrm{Cu}-\mathrm{K} \alpha$ radiation $(\lambda=0.1541$ 
$\mathrm{nm})$. Before analysis, the samples were milled into a fine powder, left to dry in an oven, and pressed uniformly into a sample holder. The scattered data were acquired within a $2 \theta$ range from $10^{\circ}$ to $90^{\circ}$. The crystallinity indices $\left(I_{\mathrm{c}}\right)$ of the Agave fibers at the raw stage, the NFC, and commercial MCC were determined using Eq. 5 (Segal et al. 1959),

$$
I_{c}=\frac{\mathrm{I}_{002}-I_{a m}}{I_{002}} \times 100
$$

where $I_{002}$ is the maximum intensity of diffraction of the (002) lattice peak $\left(22^{\circ}\right.$ to $\left.23^{\circ}\right)$, and $I_{\mathrm{am}}$ is the minimum intensity of the amorphous material at $18^{\circ}$ to $19^{\circ}$.

\section{Thermogravimetric analysis}

A NETZSCH STA 449 F3 Jupiter (Selb, Germany) thermogravimetric analyzer was used to characterize the thermal stabilities and decomposition temperatures of the Agave raw fibers and the NFC. Approximately $5 \mathrm{mg}$ of sample was placed in a platinum crucible and exposed to heat from $30{ }^{\circ} \mathrm{C}$ to $600{ }^{\circ} \mathrm{C}$ with a heating rate $30{ }^{\circ} \mathrm{C} / \mathrm{min}$. All the samples' measurements were performed under a nitrogen atmosphere.

\section{SEM analysis}

Scanning electron micrographs of the raw and acid-treated Agave fibers were recorded using a Quanta 250 (FEI, Hillsboro, OR, USA) at an accelerating voltage of 8 $\mathrm{kV}$. The milled raw fibers and ultrasonicated treated fibers were sputter coated (Emitech SC7620, Quorum Technologies, East Sussex, United Kingdom) with gold/palladium directly, to avoid charging, and a few drops of the ultrasonicated solution were gradually placed onto the two-sided conductive carbon tape on an SEM stub. Thereafter, the stub was allowed to dry in an oven. The stub was mounted on the sample stage, and the images were taken.

\section{TEM analysis}

To determine the dimensions of the Agave NFC, the acid hydrolyzed solution was ultrasonicated for $30 \mathrm{~min}$ and observed using TEM (FEI, Hillsboro, OR, USA) at an accelerating voltage of $100 \mathrm{kV}$. All the images were taken in bright-field mode. Approximately $10 \mu \mathrm{L}$ of the diluted Agave NFC suspension was placed on a TEM sample grid (carbon-coated copper grid) and left to dry at room temperature.

\section{RESULTS AND DISCUSSION}

\section{Fiber Recovery Yield, Fiber Yield Percentage, Moisture Percentage, Fiber Length, Fiber Diameter, Chemical Composition Analysis, and NFC Yield}

The average yield of the fiber and the recovery percentage were successfully estimated for the Agave plant. The recovery percentage of raw fiber was recorded (2\%) and $(36 \%)$ of fiber yield percentage. The fibers treated chemically in different stages (viz., raw, alkali treated, and bleached) are presented in Table 1. The matured raw Agave fibers were composed of $65 \%$ cellulose, $32 \%$ hemicellulose, and $3 \%$ lignin. Hemicellulose and lignin fractions were greater in the raw fiber, compared to the treated fibers. A sufficient amount of hemicellulose (decreasing from 32\% to 22\%) was eliminated after the fibers were treated with $\mathrm{NaOH}$. These results are in accordance with the results of Sghaier et al. (2012), who treated Agave fibers with 5\% of $\mathrm{NaOH}$ were 
significantly decreased from (32.1\% to $24.6 \%)$. The lignin content was reduced with $\mathrm{NaClO}_{2}$ as the bleaching treatment, with which it reacts as a lignin chloride. The bleaching treatment not only removes lignin, but it also removes some of the hemicellulose. The final cellulose content was $90.4 \%$ after the bleaching treatment. These results are in agreement with previous researchers who extracted and isolated cellulose content (97.3\%) from Agave angustifolia plant fiber (Rosli et al. 2013) and two banana pseudostem cultivars (Poovan, 59.5\%; Grand Nain, 56.9\%) (Gopinathan et al. 2017). The moisture and dry mass percentages ( $81 \%$ and $19 \%$, respectively) were recorded before and after the dry stage. Fiber length was measured to learn about the strength, evenness, and appearance. The fiber length range varied in different sizes, which were obtained during the fiber extraction and few of the fiber bundles are broken during extraction process. The average length was $106 \mathrm{~cm}$. These results show that the length of the single fiber is equal to the length of the sheath (Msahli et al. 2006). The fiber diameter was measured to know the uniformity of width. The average fiber diameter was $0.17 \mathrm{~mm}$. All the fiber bundles were found to be equal in diameter. These results show the uniformity of the fibers' width, indicating quality and flexibility (Morton and Hearle 1975). The recovery percentage of the NFC was $27.0 \%$ after acid hydrolysis, followed by ultrasonication for $30 \mathrm{~min}$, confirming the reported high holocellulose content.

Table 1. Mean Values of Fiber Recovery Yield, Fiber Yield Percentage, Moisture Percentage, Dry Matter, and Chemical Composition of Agave americana Fibers Treated Chemically at Different Stages

\begin{tabular}{|c|c|c|c|c|c|c|c|}
\hline $\begin{array}{c}\text { Fiber } \\
\text { Stage }\end{array}$ & $\begin{array}{c}\text { Fiber } \\
\text { Recovery } \\
(\%)\end{array}$ & $\begin{array}{c}\text { Fiber } \\
\text { Yield } \\
(\%)\end{array}$ & $\begin{array}{c}\text { Moisture } \\
(\%)\end{array}$ & $\begin{array}{c}\text { Dry } \\
\text { Matter } \\
(\%)\end{array}$ & $\begin{array}{c}\text { Cellulose } \\
(\%)\end{array}$ & $\begin{array}{c}\text { Hemicellulose } \\
(\%)\end{array}$ & $\begin{array}{c}\text { Lignin } \\
(\%)\end{array}$ \\
\hline $\begin{array}{c}\text { Raw } \\
\text { Fiber }\end{array}$ & $2 \pm 0.3$ & $36 \pm 1$ & $81 \pm 1$ & $19 \pm 1$ & $65 \pm 2$ & $32 \pm 2$ & $\begin{array}{c}3 \pm \\
0.3\end{array}$ \\
\hline $\begin{array}{c}\text { Alkali } \\
\text { Treated }\end{array}$ & - & - & - & - & $77 \pm 9$ & $22 \pm 8$ & $\begin{array}{c}1.4 \pm \\
0.2\end{array}$ \\
\hline Bleached & - & - & - & - & $90 \pm 5$ & $9 \pm 5$ & $\begin{array}{c}0.4 \pm \\
0.1\end{array}$ \\
\hline
\end{tabular}

\section{Morphology Analysis of Agave americana L. Fibers}

The Agave fibers treated chemically in different stages are shown in Fig. 3. The color changed from brownish (raw fiber), followed by cream to brownish (after alkali treatment), to whitish (cellulose after bleaching and acid hydrolysis). Then, the cellulose was ultrasonicated (water bath) for 30 minutes to achieve NFC. 


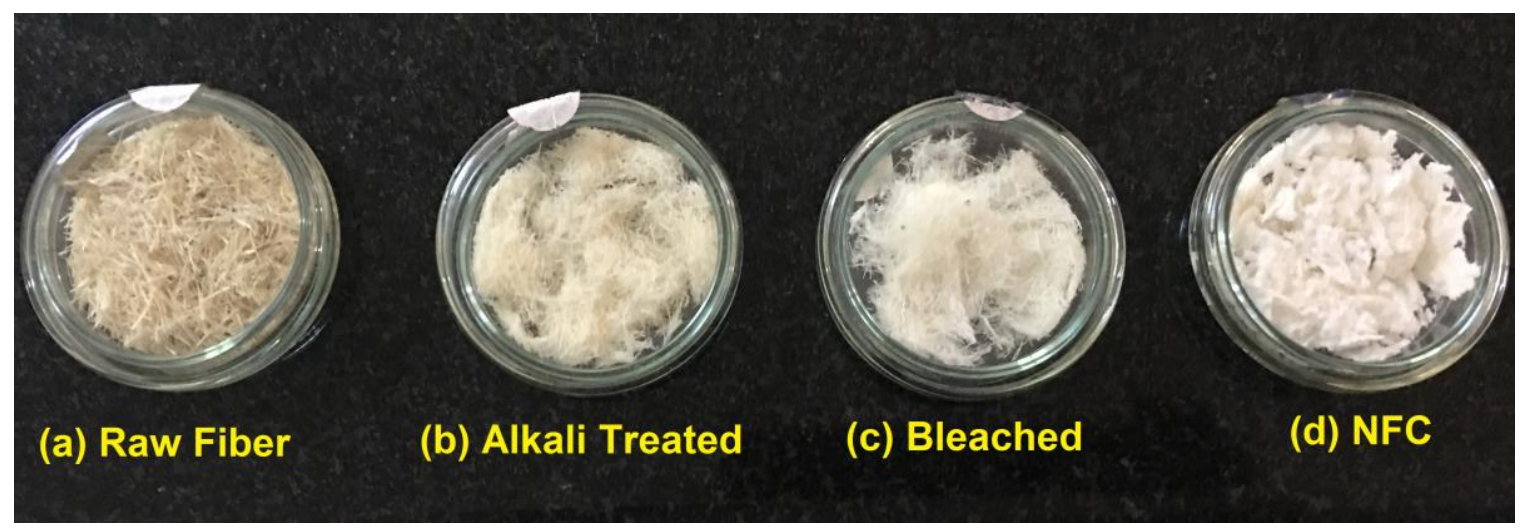

Fig. 3. Images of Agave (a) raw fiber, (b) alkali treated fiber, (c) bleached treated fiber, and (d) NFC

\section{Chemical Treatment}

The Agave fibers were acid treated with a combination of nitric acid (70\%) and acetic acid (80\%). The fiber color, which was treated with the alkali and bleaching processes, was not white. This result may be due to the strong oxidizing action and protein denaturant of nitric acid with the fibers. Generally, in plant based fibers, the chemical constituents of lignin, hemicelluloses, and other major lignocellulosic matter are removed successfully with a combination of nitric acid $(70 \%)$ and acetic acid $(80 \%)$ (Updegraff 1969). A similar acid mixture has been used for isolation of cellulose and removal of lignin from two banana cultivars (Gopinathan et al. 2017). The adopted procedure effectively eliminated the non-cellulose polysaccharides, in addition to reducing environmental risks, as well as the conventional method of delignification and bleaching (Sun et al. 2004). The complete chemistry of delignification was because of the assisting high temperatures, nitric acid concentrations that show lignin in yellow and it is soluble in acetic acid (Thomson 1838).

\section{SEM Analysis}

The raw Agave fiber and the fiber after acid treatment were characterized by SEM, which revealed the morphological changes that occurred in the process of transforming raw fiber mass into NFC (Fig. 4a). The raw Agave fiber showed serrated layers of xylem and phloem with cavity diameters of $35 \mu \mathrm{m}$ to $40 \mu \mathrm{m}$. These data were in partial agreement with previous research that measured central cavities ( $14 \mu \mathrm{m}$ to $23 \mu \mathrm{m}$ ) in banana fiber (Gopinathan et al. 2017). 

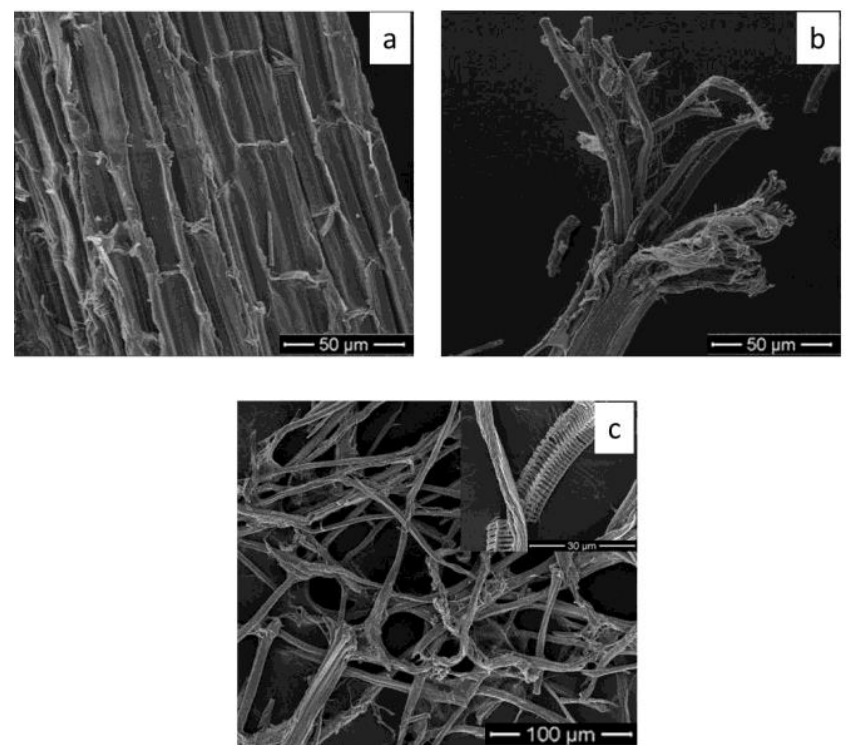

Fig. 4. SEM Images of Agave (a) raw fiber, (b) alkali-treated fiber, and (c) acid-treated fiber

After alkali treatment of the raw Agave fiber, it started to deform due to the partial removal of lignin and hemicellulose (Fig. 4b). This may be due to the fact that cementing materials (such as hemicellulose and lignin) that are present in the fiber get dissolved completely with $\mathrm{NaOH}$. Such treatment has been found to be successful in eliminating the waxy materials, pectin, lignin, and hemicellulose from the fiber surface. In the bleaching step, a microfibrillar structure was observed, indicating maximum removal of lignin and hemicellulose during the process (Sghaier et al. 2012). After acid treatment, further defibrillation occurred and transformed from microfibrils to nano size range fibrils after mechanical process (ultrasonication), with short fibrils ranging from $1 \mu \mathrm{m}$ to $2 \mu \mathrm{m}$ and long fibrils of $4 \mu \mathrm{m}$ to $6 \mu \mathrm{m}$ (Fig. 4c).

\section{TEM Analysis}

A high-resolution transmission electron micrograph was taken of the NFC to visualize the internal structure that was not visible in the scanning electron micrographs. The complete removal of cementing materials around the fiber is distinctly visible in the transmission electron micrograph in Fig. 5a. After acid hydrolysis, the fibers were disintegrated from microfibrillated cellulose to NFC after successful ultrasonication for $30 \mathrm{~min}$. The results were in accordance with previous research that achieved NFC as a filament-like structure, and the ultra-sonication time resulted in good disruption with multiple entangled networks (Pelissari et al. 2014). The transmission electron micrograph of aqueous NFC shows uniform network separation of fibrils. The average particle size distribution of the Agave NFC was $18.2 \mathrm{~nm} \pm 10.14 \mathrm{~nm}$. (Fig. 5b). These data were in agreement with earlier research on NFC from two banana pseudostem cultivars (4 nm to $6 \mathrm{~nm}$ for Poovan; $6 \mathrm{~nm}$ to $10 \mathrm{~nm}$ for Grand Nain) and MFC (5 nm) in cotton and ramie (Šturcová et al. 2004; Gopinathan et al. 2017). This result was attributed to the attractions of Van der Waals forces among the nanoparticles (Othman et al. 2012; Lani et al. 2014). The mechanical strength of the fiber is based on the fibrils' aspect ratios. It is important to know the ratio of the fibrils' lengths and diameters, as depicted in the TEM images (Fortunati et al. 2013). The aspect ratio (25 to 33) was calculated from the transmission electron micrographs. 

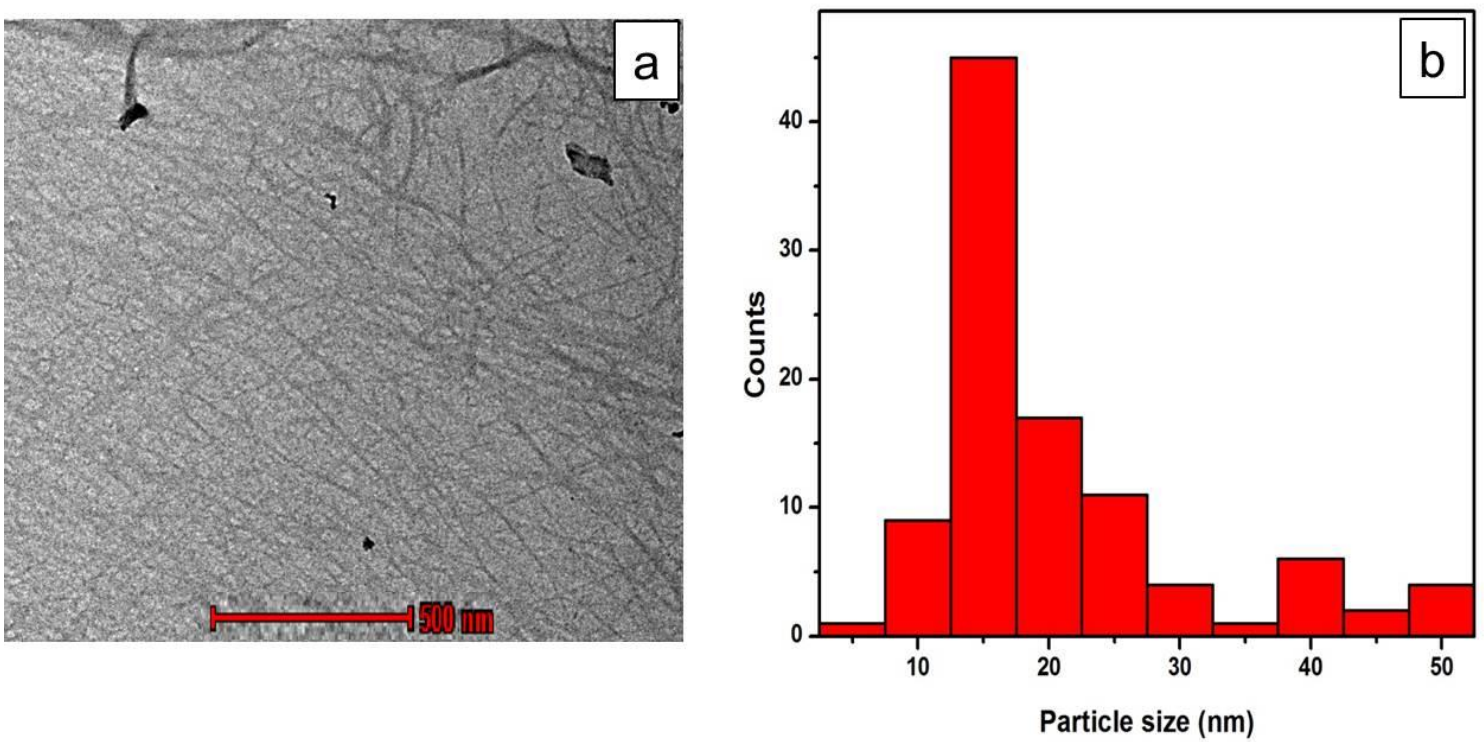

Fig. 5. (a) Transmission electron micrograph of Agave NFC and (b) Agave NFC particle size distribution

\section{FTIR Analysis}

Fourier-transform infrared spectroscopy is a useful technique to differentiate various samples based on their chemical constituents (functional groups) and to know the properties of materials. Raw fiber, NFC prepared from the Agave fibers, and commercial MCC was analyzed, and the FTIR spectra are shown in Fig. 6. The main peaks corresponding to cellulose, are shown in Table 2. The confirmation of cellulose was obtained from the peaks at $3329 \mathrm{~cm}^{-1}$ to $3330 \mathrm{~cm}^{-1}$, which corresponded to $\mathrm{OH}$ stretching. These $\mathrm{OH}$ stretching peaks were in agreement with the previous peak values at $3300 \mathrm{~cm}^{-1}$ and $3400 \mathrm{~cm}^{-1}$ (Rosli et al. 2013; Gopinathan et al. 2017). Peak shifts of C-H symmetrical stretching were in the range of $2886 \mathrm{~cm}^{-1}$ to $2900 \mathrm{~cm}^{-1}$ (Khalil et al. 2001). The FTIR peaks pertaining to $\mathrm{C}=\mathrm{O}$ stretching vibrations were in the range of $1731 \mathrm{~cm}^{-1}$ to $1734 \mathrm{~cm}^{-1}$, which confirms functional groups of pectin, hemicellulose, lignin, carboxylic groups of ferulic and p-coumaric acid, and ester groups of acetyl and uronic acid. Sun et al. 2005; Sain and Panthapulakkal 2006). Water can be found in cellulose due to the strong interaction between them. The apparent spectral peaks at $1601 \mathrm{~cm}^{-1}$ to 1653 $\mathrm{cm}^{-1}$ corresponded to $\mathrm{OH}$ bending of absorbed water (Le Troedec et al. 2008; Gopinathan et al. 2017). The peak values of C-O-C pyranose ring stretching were in the range of $1019 \mathrm{~cm}^{-1}$ to $1031 \mathrm{~cm}^{-1}$ in raw fiber, NFC and MCC samples. These peaks' increase was due to the band intensity and crystallinity of samples (Elanthikkal et al. 2010). The small peaks at $663 \mathrm{~cm}^{-1}$ to $664 \mathrm{~cm}^{-1}$ in raw fiber, NFC, and MCC samples were attributed to C$\mathrm{OH}$ out-of-plane bending. The present FTIR results indicated that the process conditions were successful in eliminating some of lignin and hemicellulose during the delignification process. 


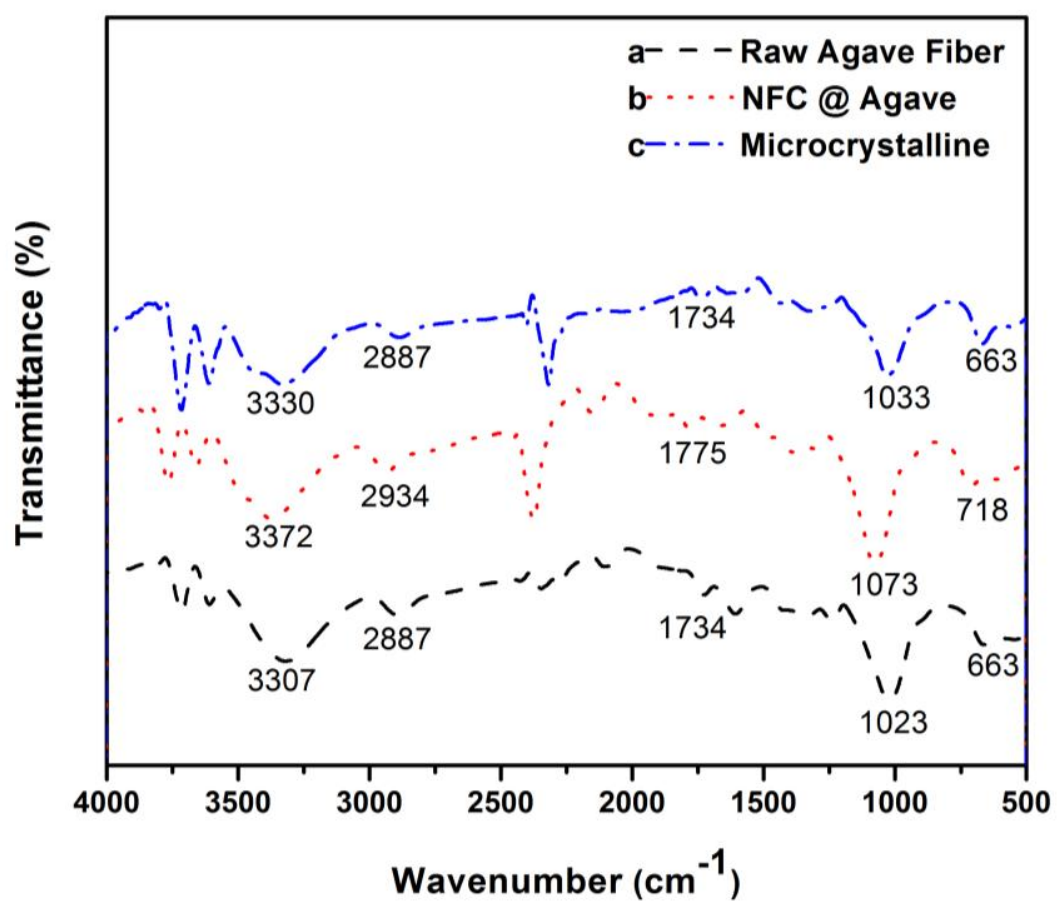

Fig. 6. FTIR spectra of Agave (a) raw fiber, (b) NFC, and (c) Microcrystalline

Table 2. FTIR Peaks of the Agave Raw Fiber, Agave NFC, and MCC

\begin{tabular}{|c|c|c|c|c|c|}
\hline Sample & $\begin{array}{c}\mathrm{OH} \\
\text { Stretching } \\
\left(\mathrm{cm}^{-1}\right)\end{array}$ & $\begin{array}{c}\mathrm{C}-\mathrm{H} \\
\text { Stretching } \\
\left(\mathrm{cm}^{-1}\right)\end{array}$ & $\begin{array}{c}\mathrm{C}=\mathrm{O} \\
\text { Stretching } \\
\left(\mathrm{cm}^{-1}\right)\end{array}$ & $\begin{array}{c}\text { C-O-C } \\
\text { Pyranose } \\
\text { Ring } \\
\text { Vibrations } \\
\left(\mathrm{cm}^{-1}\right)\end{array}$ & $\begin{array}{c}\text { C-H Deformation } \\
\text { with a Ring } \\
\text { Vibration and O-H } \\
\text { Bending }\left(\mathrm{cm}^{-1}\right)\end{array}$ \\
\hline $\begin{array}{c}\text { Agave } \\
\text { raw fiber }\end{array}$ & 3307 & 2887 & 1734 & 1023 & 663 \\
\hline $\begin{array}{c}\text { Agave } \\
\text { NFC }\end{array}$ & 3372 & 2934 & 1775 & 1073 & 718 \\
\hline MCC & 3330 & 2887 & 1734 & 1033 & 663 \\
\hline
\end{tabular}

\section{XRD Measurements}

The XRD patterns of the raw Agave fibers, the MCC, and the NFC showed peaks at approximately $2 \theta=15.70^{\circ}, 22.34^{\circ}, 14.58^{\circ}, 22.50^{\circ}, 34.63^{\circ}, 15.11^{\circ}, 22.50^{\circ}$, and $34.52^{\circ}$ (Fig. 7), indicating the distinctive cellulose I structure. Among all the peaks, there were slight differences in the peak intensities, representing fiber crystallinity changes. For some plant derived fibers (such as cotton, banana pseudostem fiber, and flax) with high cellulose content, three peaks at approximately $16^{\circ}, 16.6^{\circ}$, and $16.7^{\circ}$ are observed. However, for the raw Agave fibers, only one broad peak $\left(15.70^{\circ}\right)$ was observed; this result may be due to the predominance of amorphous material covering the two peaks (Subramanian et al. 2005; Tserki et al. 2005). In Fig. 7b, the peaks of the Agave NFC at $15.11^{\circ}, 22.50^{\circ}$, and $34.52^{\circ}$ were similar to the peaks in cotton, flax, and banana pseudostem fiber, with a sharp peak at $22.50^{\circ}$, showing a greater crystallinity by removing more amorphous domains in the fiber (Rosli et al. 2013; Gopinathan et al. 2017). The crystallinity indices for the Agave raw fiber, the NFC, and the commercial MCC were $50.10 \%, 64.11 \%$, and $70.40 \%$, respectively (Table 3), a clear increase from 
before to after the chemical treatment. Moreover, the crystallinity index is used to show the order of crystalline instead of the crystallinity of crystalline regions (Rosli et al. 2013). The increase in crystallinity index was mainly because of the partial elimination of amorphous constituents and the crystalline regions being arranged in ordered manner.

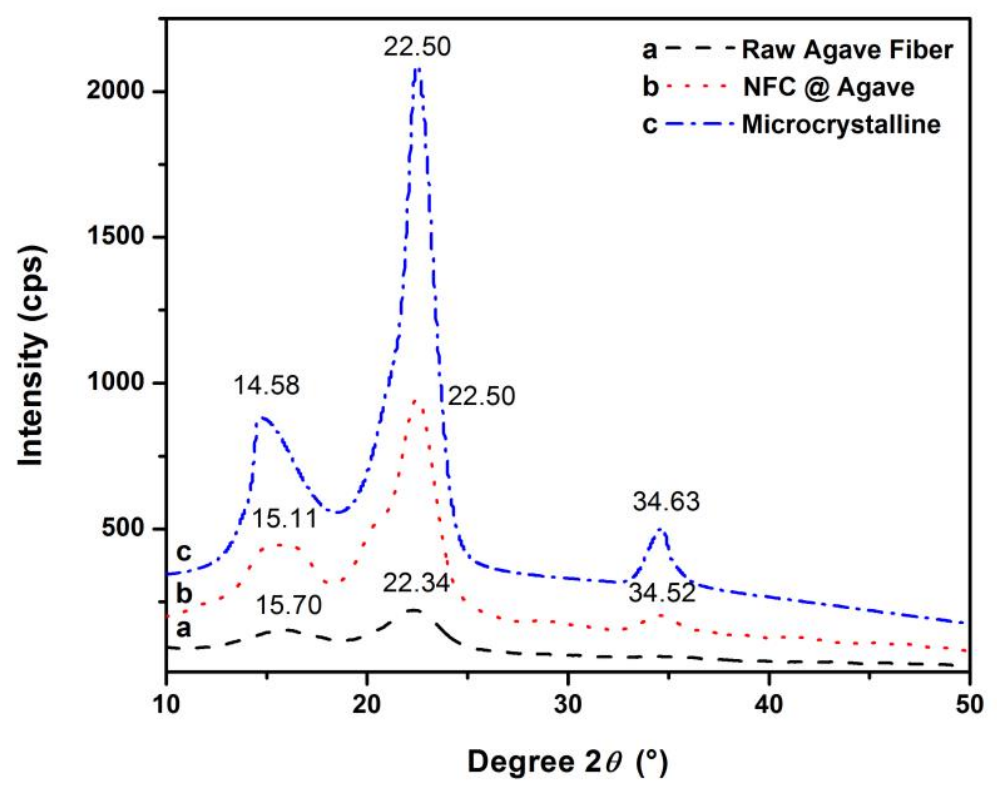

Fig. 7. XRD patterns of Agave (a) raw fiber, (b) NFC, and (c) Microcrystalline

Table 3. Crystallinity Indices and $2 \theta$ Values of Agave Raw Fibers, Agave NFC, and MCC

\begin{tabular}{|c|c|c|}
\hline Sample & Crystallinity Index & $2 \theta\left(^{\circ}\right)$ \\
\hline Agave raw fiber & 50.10 & $15.70,22.34$ \\
\hline Agave NFC & 64.11 & $15.11,22.50,34.52$ \\
\hline MCC & 70.40 & $14.58,22.50,34.63$ \\
\hline
\end{tabular}

\section{Thermal Stability Analysis}

Lignocellulosic materials are routinely characterized by thermal behavior, crystallinity, structure, and chemical composition (Fisher et al. 2002). The TG curves for the Agave raw fibers are shown in Fig. 8a. The initial weight loss of raw Agave fibers was observed between $25{ }^{\circ} \mathrm{C}$ and $177.3{ }^{\circ} \mathrm{C}$ due to removal of moisture. This first step is not general in all other fiber samples and this is because of the fiber was stabilized at $110{ }^{\circ} \mathrm{C}$ for 10 minutes. The second weight loss of raw Agave fibers found to be at $350.8{ }^{\circ} \mathrm{C}$, and this is due to thermal depolymerization of hemicellulose, and breakdown of glycosidic linkages of cellulose (Karakoti et al. 2020). In Fig. 8b, the initial weight losses of the Agave raw fiber started at $51.5{ }^{\circ} \mathrm{C}$ by complete evaporation of moisture, followed by degradation of hemicellulose and $\alpha$-cellulose at $203.0{ }^{\circ} \mathrm{C}$ and $331.8{ }^{\circ} \mathrm{C}$, respectively (Basak et al. 1993). The initial degradation of the NFC was recorded at $275.4{ }^{\circ} \mathrm{C}$, after which the degradation was rapid, losing approximately $80 \%$ of the initial weight at 374.7 ${ }^{\circ} \mathrm{C}$. The char residue was higher in the case of $\mathrm{NFC}$, and this was because of hemicellulose, $\alpha$-cellulose, lignin, and other substituents present in the fiber and which were found to be absent completely in the NFC fiber samples after complete degradation 
of lignin, which was confirmed further by FT-IR spectra. The weight loss occurring from $297.4{ }^{\circ} \mathrm{C}$ to $353.8^{\circ} \mathrm{C}$ was due to the loss of $\alpha$-cellulose and hemicellulose (Gopinathan et al. 2017). The peak due to lignin was absent, due to the negligible presence in the raw fiber and NFC. The greater thermal stability of the NFC might be due to its high crystallinity index, which was discussed in the XRD characterization section (Rosli et al. 2013).
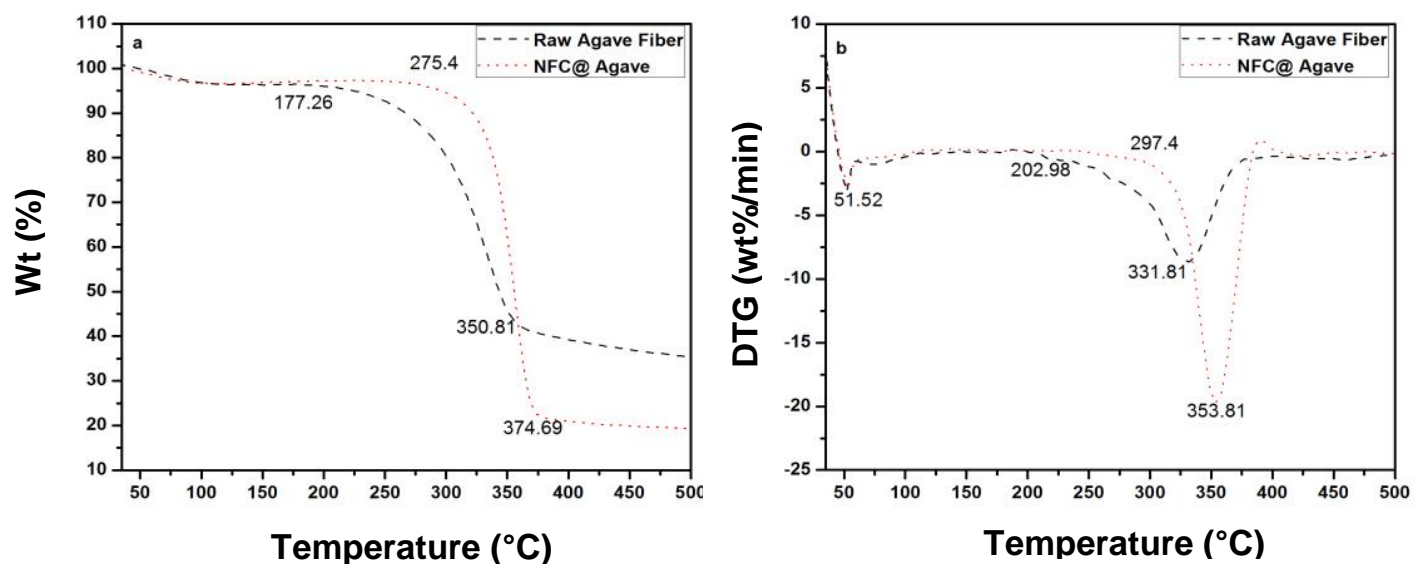

Fig. 8. (a) TG and (b) DTG curves of Agave raw fiber and NFC

The NFC from Agave americana was considered a suitable candidate for developing an eco-friendly, biodegradable nano-film packaging, by reducing the postharvest losses of perishables and prolonging the storage life of fruits and vegetables. The fiber recovery was $2 \%$, the NFC yield was $27.0 \%$, and the crystallinity index was greater than that of the raw fiber. The thermal degradation exhibited a peak at $353.81^{\circ} \mathrm{C}$, with an average particle size of $18 \mathrm{~nm} \pm 10.14 \mathrm{~nm}$. This potential green fiber extracted NFC with high strength could be used as a reinforcing material in composites and possibly be a replacement for petroleum-based plastics. A nano-film derived from the plant fiber could also be developed, which would be environmentally friendly.

\section{CONCLUSIONS}

1. The fresh and matured Agave plants were collected and effectively isolated and chemically treated with $2 \%$ to $4 \%$ of $\mathrm{NaOH}$, which successfully eliminated the hemicellulose, followed by delignification with $4 \% \mathrm{NaClO}_{2}$.

2. The NFC was successfully isolated by acid hydrolysis (nitric acid 70\%; acetic acid $80 \%$ ) coupled with ultrasonication for $30 \mathrm{~min}$.

3. The functional, structural, and thermal stabilities of the Agave raw fiber and NFC samples were analyzed using FTIR, XRD, TG, and DTG.

4. The cellulose content increased from $65 \%$ to $90 \%$ from the raw to the NFC stage.

5. The NFC yield was $27.0 \%$ after acid hydrolysis.

6. The crystallinity index increased from $50.10 \%$ to $64.11 \%$ from the raw fiber to the 
NFC sample.

7. The transmission electron micrograph revealed the successful disintegration of the fiber from the micro to the nano range, with an average particle size of $18.2 \mathrm{~nm} \pm$ $10.14 \mathrm{~nm}$.

8. The NFC was a suitable candidate as a reinforcing filler material in biodegradable packaging composites as an alternative to synthetic plastics.

\section{ACKNOWLEDGMENTS}

K. S. Subramanian and his team are thankful to DST-Nanomission Pulses for financial aid throughout the research duration. The authors wish to thank Mr. Badal Kumar Biswal (Ph.D. Scholar) and Mr. M. Pragadeesh (Senior Research Fellow) for their constant and technical support.

\section{REFERENCES CITED}

ASTM D1166-84 (2001). "Standard test method for methoxyl groups in wood and related materials," ASTM International, West Conshohocken, PA. DOI: 10.1520/D116684R01

Basak, R. K., Saha, S. G., Sarkar, A. K., Saha, M., Das, N. N., and Mukherjee, A. K. (1993). "Thermal properties of jute constituents and flame retardant jute fabrics," Textile Research Journal 63(11), 658-666. DOI: 10.1177/004051759306301107

Bismarck, A., Mishra, S., and Lampke, T. (2005). "Plant fibers as reinforcement for green composites," in: Natural Fibers, Biopolymers, and Biocomposites, A. K. Mohanty, M., Misra, and L. T. Drzal (eds.), CRC Press, Boca Raton, FL, USA, pp. 52-128. DOI: 10.1201/9780203508206.ch2

Brinchi, L., Cotana, F., Fortunati, E., and Kenny, J. M. (2013). "Production of nanocrystalline cellulose from lignocellulosic biomass: Technology and applications," Carbohydrate Polymers 94(1), 154-169. DOI: 10.1016/j.carbpol.2013.01.033

Elanthikkal, S., Gopalakrishnapanicker, U., Varghese, S., and Guthrie, J. T. (2010). "Cellulose microfibres produced from banana plant wastes: Isolation and characterization," Carbohydrate Polymers 80(3), 852-859. DOI: 10.1016/j.carbpol.2009.12.043

Fisher, T., Hajaligol, M., Waymack, B., and Kellogg, D. (2002). "Pyrolysis behavior and kinetics of biomass derived materials," Journal of Analytical and Applied Pyrolysis 62(2), 331-349. DOI: 10.1016/S0165-2370(01)00129-2

Fortunati, E., Puglia, D., Monti, M., Peponi, L., Santulli, C., Kenny, J. M., and Torre, L. (2013). "Extraction of cellulose nanocrystals from Phormium tenax fibres," Journal of Polymers and the Environment 21(2), 319-328. DOI: 10.1007/s10924-012-0543-1

FAOSTAT. Statistic Division. Food and Agriculture Organization, (2017) Production Crops All Data, Rome, Italy: FAO. <http://www.fao.org/faostat/en/\#data/QC/visualize>.

Gopinathan, P., Subramanian, K. S., Paliyath, G., and Subramanian, J. (2017). "Genotypic variations in characteristics of nano-fibrillated cellulose derived from 
banana pseudostem," BioResources 12(4), 6984-7001. DOI:

10.15376/biores.12.4.6984-7001

Hubbe, M. A., Ferrer, A., Tyagi, P., Yin, Y., Salas, C., Pal, L., and Rojas, O. J. (2017).

"Nanocellulose in thin films, coatings, and plies for packaging applications: A review," BioResources 12, 2143-2233. DOI: 10.15376/biores.12.1.2143-2233

Ilyas, R. A., Sapuan, S. M., Ibrahim, R., Abral, H., Ishak, M. R., Zainudin, E. S., and Syafri, E. (2019). "Effect of sugar palm nanofibrillated cellulose concentrations on morphological, mechanical and physical properties of biodegradable films based on agro-waste sugar palm (Arenga pinnata (Wurmb.) Merr) starch,"Journal of Materials Research and Technology 8(5), 4819-4830. DOI: 10.1016/j.jmrt.2019.08.028

Khalil, H. P. S. A., Ismail, H., Rozman, H. D., and Ahmad, M. N. (2001). "The effect of acetylation on interfacial shear strength between plant fibres and various matrices," European Polymer Journal 37(5), 1037-1045. DOI: 10.1016/S0014-3057(00)00199-3

Kolte, P., Daberao, A., and Miss Sharma, A. (2012). "Agave americana: The natural leaf fibre," Textile Review 7, 1-5.

Karakoti, A., Biswas, S., Aseer, J. R., Sindhu, N., and Sanjay, M. R. (2020).

"Characterization of microfiber isolated from Hibiscus sabdariffa var. altissima fiber by steam explosion,” Journal of Natural Fibers, 17(2), 189-198. DOI: 10.1080/15440478.2018.1477085

Lani, N. S., Ngadi, N., Johari, A., and Jusoh, M. (2014). "Isolation, characterization, and application of nanocellulose from oil palm empty fruit bunch fiber as nanocomposites," Journal of Nanomaterials 2014. DOI: 10.1155/2014/702538

Le Troedec, M., Sedan, D., Peyratout, C., Bonnet, J. P., Smith, A., Guinebretiere, R., Gloaguen, V., and Krausz, P. (2008). "Influence of various chemical treatments on the composition and structure of hemp fibres," Composites Part A: Applied Science and Manufacturing 39(3), 514-522. DOI: 10.1016/j.compositesa.2007.12.001

Morton, W. E., and Hearle, J. W. S. (1975). Physical Properties of Textile Fibres, Butterworth and Company, London, UK.

Msahli, S., Sakli, F., and Drean, J.-Y. (2006). "Study of textile potential of fibres extracted from Tunisian Agave americana L.," AUTEX Research Journal 6(1), 9-13.

Msahli, S., Ydrean, J., and Sakli, F. (2005). "Evaluating the fineness of Agave americana L. fibers," Textile Research Journal 75(7), 540-543. DOI:

10.1177/0040517505053808

Marinho, N. P., de Cademartori, P. H. G., Nisgoski, S., de Andrade Tanobe, V. O., Klock, U., and de Muñiz, G. I. B. (2020). "Feasibility of ramie fibers as raw material for the isolation of nanofibrillated cellulose," Carbohydrate Polymers 230, 115579. DOI: 10.1016/j.carbpol.2019.115579

Naik, R. K., Dash, R. C., and Goel, A. K. (2013). "Mechanical properties of sisal (A. sisalana) relevant to harvesting and fibre extraction," International Journal of Agricultural Engineering 6(2), 423-426.

Nascimento, D. M., Nunes, Y. L., Figueirêdo, M. C. B., de Azeredo, H. M. C., Aouada, F. A., Feitosa, J. P. A., Rosa, M. F., and Dufresne, A. (2018). "Nanocellulose nanocomposite hydrogels: Technological and environmental issues," Green Chemistry 20(11), 2428-2448. DOI: 10.1039/C8GC00205C

Oksman, K., and Sain, M. (eds.) (2006). Cellulose Nanocomposites: Processing, Characterization, and Properties, American Chemical Society, Washington, DC, USA. DOI: $10.1021 / \mathrm{bk}-2006-0938$

Othman, S. H., Abdul Rashid, S., Mohd Ghazi, T. I., and Abdullah, N. (2012). 
"Dispersion and stabilization of photocatalytic $\mathrm{TiO}_{2}$ nanoparticles in aqueous suspension for coatings applications," Journal of Nanomaterials 2012. DOI: $10.1155 / 2012 / 718214$

Pelissari, F. M., do Amaral Sobral, P. J., and Menegalli, F. C. (2014). "Isolation and characterization of cellulose nanofibers from banana peels," Cellulose 21(1), 417432. DOI: $10.1007 / \mathrm{s} 10570-013-0138-6$

Ramesh, M., Palanikumar, K., and Reddy, K. H. (2017). "Plant fibre based biocomposites: Sustainable and renewable green materials," Renewable and Sustainable Energy Reviews 79, 558-584. DOI: 10.1016/J.RSER.2017.05.094

Rosli, N. A., Ahmad, I., and Abdullah, I. (2013). "Isolation and characterization of cellulose nanocrystals from Agave angustifolia fibre," BioResources 8(2), 1893-1908. DOI: 10.15376/biores.8.2.1893-1908

Rowell, R. M. (2012). Handbook of Wood Chemistry and Wood Composites, Second Edition, CRC Press, Boca Raton, FL, USA.

Sain, M., and Panthapulakkal, S. (2006). "Bioprocess preparation of wheat straw fibers and their characterization," Industrial Crops and Products 23(1), 1-8. DOI: 10.1016/j.indcrop.2005.01.006

Sarkar, M.K., and Sarcar, A.B. (1996). "Agave, a multipurpose dryland plant”, The Hindu, Science and Technology, 1-6, (https://biogov.in/article/agave-a-multipurosedryland-plant)

Segal, L., Creely, J. J., Martin, Jr., A. E., and Conrad, C. M. (1959). “An empirical method for estimating the degree of crystallinity of native cellulose using the X-ray diffractometer," Textile Research Journal 29(10), 786-794. DOI: 10.1177/004051755902901003

Sghaier, A. E. O. B., Chaabouni, Y., Msahli, S., and Sakli, F. (2012). "Morphological and crystalline characterization of $\mathrm{NaOH}$ and $\mathrm{NaOCl}$ treated Agave americana L. fiber," Industrial Crops and Products 36(1), 257-266. DOI: 10.1016/j.indcrop.2011.09.012

Singh, K. (1999). "Problem and prospects of sisal cultivation in India," in: National Seminar on JAF (BCKV, Kalyani), pp. 97-102.

Šturcová, A., His, I., Apperley, D. C., Sugiyama, J., and Jarvis, M. C. (2004). "Structural details of crystalline cellulose from higher plants," Biomacromolecules 5(4), 1333 1339. DOI: $10.1021 / \mathrm{bm} 034517 \mathrm{p}$

Subramanian, K., Senthil Kumar, P., Jeyapal, P., and Venkatesh, N. (2005). "Characterization of ligno-cellulosic seed fibre from Wrightia tinctoria plant for textile applications-An exploratory investigation," European Polymer Journal 41(4), 853-861. DOI: 10.1016/j.eurpolymj.2004.10.037

Sun, J. X, Sun, X. F, Zhao, H., and Sun, R.-C. (2004). "Isolation and characterization of cellulose from sugarcane bagasse," Polymer Degradation and Stability 84(2), 331339. DOI: $10.1016 /$ j.polymdegradstab.2004.02.008

Sun, X. F., Xu, F., Sun, R. C., Fowler, P., and Baird, M. S. (2005). "Characteristics of degraded cellulose obtained from steam-exploded wheat straw," Carbohydrate Research 340(1), 97-106. DOI: 10.1016/j.carres.2004.10.022

Syracuse University, New York State. (2011). CHE 276 - Organic Chemistry I Laboratory - Acalog ACMS ${ }^{\mathrm{TM}}$, Appendix, <http://coursecatalog.syr.edu/preview_course_nopop.php?catoid=3\&coid=9148>.

Tanpichai, S., Witayakran, S., Srimarut, Y., Woraprayote, W., and Malila, Y. (2019). "Porosity, density and mechanical properties of the paper of steam exploded bamboo 
microfibers controlled by nanofibrillated cellulose." Journal of Materials Research and Technology 8(4), 3612-3622. DOI: 10.1016/j.jmrt.2019.05.024

Thomson, T. (1838). Chemistry of Organic Bodies, Vegetables - Google Play, Foreign Bookseller and Publisher, 219 Regent street, Paris.

Tserki, V., Matzinos, P., Kokkou, S., and Panayiotou, C. (2005). "Novel biodegradable composites based on treated lignocellulosic waste flour as filler. Part I. Surface chemical modification and characterization of waste flour," Composites Part A: Applied Science and Manufacturing 36(7), 965-974. DOI: 10.1016/j.compositesa.2004.11.010

Updegraff, D. M. (1969). "Semimicro determination of cellulose in biological materials," Analytical Biochemistry 32(3), 420-424. DOI: 10.1016/S0003-2697(69)80009-6

Article submitted: October 22, 2019; Peer review completed: January 14, 2020; Revised version received: January 26, 2020; Accepted: January 27, 2020; Published: February 12, 2020.

DOI: 10.15376/biores.15.2.2442-2458 